\title{
Analysis of the Financial Performance of Selected Cement Industries of Bangladesh
}

\author{
Subarna Ershad*, Md. Minhaz Uddin**, \& Md. Omar Faruk*** \\ *Assistant Director (Research), Research Department, Bangladesh Bank. \\ **Department of Economics, Sheikh Fazilatunnesa Mujib University, Jamalpur, 2000. \\ ***Deputy Director (Research), Monetary Policy Department, Bangladesh Bank. \\ farukecoju38@gmail.com
}

\begin{abstract}
This paper aims to analyze the financial performance of industries of Bangladesh, which are performing a crucial role in the current economic development trend of the country. Heidelberg Cement Bangladesh Ltd, Crown Cement, Lafarge Holcim and Meghna Cements are selected for analysis for their $70 \%$ of market share coverage of the cement industry. Competency of selected leading four cement companies are looked over here with some financial parameters like Return on Asset (ROA), Return on Equity (ROE), Earnings Per Share (EPS), Total Debt Ratio (TDR), Current Ratio (CR), Net Working Capital Ratio (NWCR), Assets Turnover Ratio (ATR) and mean value analysis technique. In preferred financial parameters and mean value analysis technique Heidelberg Cement Bangladesh Ltd has a good position, and in most cases, Meghna Cements obtained the lowest score. To attain desired efficacy in the cement industry of Bangladesh shortly, some prime recommendations such as reduction of production cost, prioritization on economies of scale, and business augmentation have come up here.
\end{abstract}

Key Words: Financial Performance, Ratio Analysis, Cement Industry.

\section{How to Cite}

Ershad, S., Uddin, Md. M., \& Faruk, Md. O. (2021). Analysis of the financial performance of selected cement industries of Bangladesh. International Journal of Finance Research, 2(1). 46-57. DOI: https://doi.org/10.47747/ijfr.v2i1.334.

\section{Introduction}

According to Bangladesh Cement Manufacturers Association (BCMA), 76 companies are playing in this sector. The selected four covers $70 \%$ of the market share. Their business model and competency performance are recently analyzed according to their annual report 'Chhatak Cement Factory', the first cement factory of Bangladesh, started its journey in 1941, long before the emergence of Bangladesh in the world map (Chhatak Cement Factory, 2021). Since then, the cement industry has grown a lot, where 31 companies are currently running a business (Bangladesh Business Directory, n.d). The total world production of cement was expected to be around 4.4 billion metric tons in 2020, and during 2016, the global production capacity of cement stood at 4200 million tons (Teri, 2017). As per one of the (UN, 2014), reports the majority of the 2.5 billion new urban inhabitants was projected to be in Africa and Asia in the period to 2050. This indicates the future high demand for cement 
consumption of the developing nations. As one of the fastest-growing economies with a growth rate of 8.15 per cent recorded in the fiscal year 2019 (Bangladesh Bank, 2021), Bangladesh will undoubtedly be a part of this massive concrete urbanization and development. The cement industry is expected to be a booming sector (Abedin, 2020). More than USD3.5 billion was budgeted in FY19 for the seven infrastructure megaprojects, including bridges, rail lines, power plants, and a metro rail (as cited in Lightcastle Analytics Wing, 2019). To that end, it is important to analyze the prospect of the cement industry of Bangladesh. There have been significant research works in the field of the cement industry. This review article is an addition to that whereby we focused only on some financial key performance indicators (KPIs) of selected firms of Bangladesh in recent years. By reviewing the financial KPIs, we can have a clear picture of the financial performance, efficiency and potentiality of the firms which have been dominating the market and thus the industry lately. An overview of the financial health of the significant firms and companies are therefore expected to improve the decision-making process of the stakeholders in future.

\section{Literature Review}

Daryanto (2018) conducted a study on measuring the financial performance of the cement industry during infrastructure development in Indonesia by using the decree of the ministry of SOEs No.KEP-100/MBU/2020 and descriptive financial ratio on two state-owned cement industries, PT. Semen (Indonesia) and PT Semen (Baturaja). The study showed PT. SB and PT. SI ran the business on firm financial performance in the periods. Furthermore, it gave some excellent advice for managers of the cement industry about financial performance.

Dhivya et al. (2017) conducted a study on the financial performance of the cement industry of ACC Limited in India. The analysis of the study was for the periods of 2011-2015 by using liquidity ratio, probability ratio, solvency ratio, and trend analysis. The study's main aim was to analyze the probability, liquidity, operational position and examine the company's financial structure. The study showed that the liquidity position of the company was satisfactory. Hence, the company met its short-term liabilities. Nevertheless, the profitability position was not much attractive. They recommended maintaining good cash positions and increasing the effective utilization of sales.

Gopi (2018) conducted a study on the financial performance of the cement industry in India by using the extended DuPont approach of three cement industries. The extended DuPont approach emphasized ROE, pretax margin, asset turnover, interest burden, tax efficiency and equity multiplier. The results showed a decline in the profitability (ROE) during the periods, and the financial performance of all three companies seemed to be similar by ROE with minimal deviation. It also showed that the calculation of ROE was not relevant for making rational economic decisions.

Hoque, et al. (2015) studied working capital management and profitability of the cement industry in Bangladesh. They research six listed cement companies using ratio analysis, correlation matrix and regression analysis based on secondary data. The study found that profitability and working capital positions over the study period were not satisfactory, and there was a significantly positive correlation between profitability and working capital components. Moreover, the impact of day sales outstanding on profitability ratios was negative. The study recommended that the selected cement companies should reduce day sales outstanding to improve profitability. 
Hossain \& Huq (2014) conducted a study on the credit strength of the cement industry in Bangladesh by using Altman's Z score and ratio analysis. The study showed that only the Heidelberg cement industry stayed in the safe zone, but other companies could not move into the safe zone because of their limited liquidity ratios. However, the trend of growth and performance of the cement industry increased day by day. They maintained the growth rate at around 20 per cent to 25 per cent in the medium to long term. The result also showed that only 20 per cent of the companies were in a safe position. However, the present study has made an effort to the financial performance of cement industries in Bangladesh.

Kaura \& Balasubramaniam (1979) conducted a study on inter-firm comparison of financial performance of selected cement companies in India by using ratio analysis. The result showed that liquidity, profitability, and financial structure ratios declined during the study period. It also showed that many cement industries' profitability and liquidity position had been constrained because of inadequate supply of raw materials and insufficient power supply.

Majeed, et al. (2017) conducted a study on the analysis of the financial progress of the cement industry in Pakistan by using Altman's Z score. The study result showed that the analysis of the financial progress was satisfactory during the study period. They recommended to the investors to invest their money for making a high rate of return. The analysis of the study periods was better than the past analysis.

Mizan \& Hossain (2014) examined the financial soundness of the cement industry of Bangladesh. They analyzed five different cement companies by using Altman's Z-score and used one way ANOVA techniques. However, the study showed that only two companies were financially strong position, one was financially sound, but the other two were at serious risk of financial distress. It also recommended that the managers should take the necessary steps to reverse the situation.

Muslumovi (2005) studied privatized companies' financial and operating performance in Turkish cement industries. The main aim of the study was to examine the impact of privatization on financial and operating performance. Findings of this study showed that privatization was declining the value-added, shareholders profitability and ROA. It also showed that privatization did not improve the efficiency of the cement industries. However, the findings were inconsistent with prior cross-sectional studies done in various countries regarding privatization.

Rajashekar \& Keshavarz (2019) researched the impact of environmental management accounting on the financial performance of the cement industry in India. They analyzed two different companies by using ratio analysis. The study's main aim was to find a relationship between the factors of environmental management accounting and financial performance. The study showed that the two selected companies' environmental management accounting and reporting performance gradually improved concerning environmental disclosure practices. Both the companies had justified energy consumptions practices and effective use of fossil fuels.

Rezina, et al. (2020) conducted a study on profitability determinants of the cement industry in Bangladesh. The main aim of the study was to examine the impact of firm-specific and macroeconomic factors in determining the profitability of the cement industry of Bangladesh with all listed cement industries in the stock exchange by using ROA, the expense to revenue 
ratio, leverage, age, inflation rate, GDP growth rate and real interest rate. ROA was considered as a profitability measurement of the firms. The study found that leverage as a firm-specific variable and GDP growth rate, actual interest rate as macroeconomic variables had a significant impact on profitability. The results showed that firm size, age, GDP growth rate and real interest rate positively impacted. In contrast, the expense to revenue ratio, leverage and inflation harmed the profitability.

Saeedi, A. \& Mahmoodi (2011) conducted research on the relationship between capital structure and firms' performance on 320 listed companies of Tehran Stock Exchange for 2002-2009. The study was conducted by four measurement techniques- ROA, ROE, EPS and Tobin's Q as the dependent variables and three capital structures as independent variables. The analysis showed no significant difference between ROE and capital structure, also showed that firm performance, which was made by calculating EPS and Tobin's Q, was significantly and positively associated with capital structure while showed a negative relationship between capital structure and ROA.

San \& Heng (2011) researched the Malaysian construction sector's capital structure and corporate performance using ROA, ROE, and GM measurements techniques. The study was conducted for finding out the relationship between capital structure and corporate performance of firms before and during the crisis (2007) over 49 construction companies. Moreover, the results showed a relationship between capital structure and corporate performance and showed no relationship between the variables investigated.

Soni (2018) conducted a study on the financial performance of JK cement of India using ratio analysis techniques. The objective of the study was to analyze the financial positions of selected companies. The study showed that the current and quick ratios were below the standard but fulfilled its short-term liabilities. The debt-equity ratio was more than the standard level, and the inventory turnover ratio fluctuated in research periods. The study suggested that if the JK cement could not decrease the debt-equity ratio, it might be at risk of bankruptcy.

Venkatacham \& Kasthuri (2016) conducted a study on the financial performance of the cement industry in India by using an analysis of variance (ANOVA) for the periods of 20062007 to 2015-2016. The study's objective was to examine the financial performance of the cement industry in India and investigate the factors affecting the cement industry based on a profitability model. The study result showed that all the ratios analyses impacted the profitability positions of the cement industries. The study recommended that the industry reduce the interest burden by giving quality products and building brand image. It also recommended that management should utilize maximum production capacity.

\section{Research Method}

This study aims to show the current financial health of cement industries of selected companies in Bangladesh. This study is based on comparative analysis and is quantitative. The scope of the study is limited to the only cement industry. This review was conducted based on secondary data collected from audited financial statements of selected companies' publications, such as: Annual Report of Crown Cement 2015-2019, Annual Report of Heidelberg Cement 2015-2019, Annual Report of LafargeHolcim Bangladesh 2015-2019, Annual Report of Meghna Cement Mills 2015-2019. For empirical analysis, the study covered a period from 2015 to 2019. Five years of data are taken due to the availability of 
reliable data sources. Four cement companies- Heidelberg Cement Bangladesh Ltd, Crown Cement, Lafarge Holcim and Meghna Cements Mills Ltd, had been selected for this study because they play a vital role in this industry. Based on the data of published annual reports of the selected companies, the study measured the financial parameters like Return on Asset (ROA), Return on Equity (ROE), Earnings Per Share (EPS), Total Debt Ratio (TDR), Current Ratio (CR), Net Working Capital Ratio (NWCR), Assets Turnover Ratio (ATR), Account Receivable Turnover Ratios (ARTR) as the financial KPIs to examine the performance of the cement industry and compare the data of the selected companies.

\section{Findings and Discussions}

Under this section, the study analyses the financial parameters, like ROA, ROE, EPS, TDR, CR, NWCR, ATR, and ARTR of the DSE listed four cement companies in Bangladesh.

\subsection{Return on Asset (ROA)}

Return on asset indicates how profitable a company is relative to its total assets $(\mathrm{ROA}=\mathrm{Net}$ income/Average total assets).

Table-1: ROA of selected cement companies (In percentage)

\begin{tabular}{|l|c|c|c|c|c|c|}
\hline Companies & 2015 & 2016 & 2017 & 2018 & 2019 & Mean \\
\hline $\begin{array}{l}\text { Heidelberg Cement Bangladesh } \\
\text { Ltd }\end{array}$ & 14.34 & 14.80 & 9.20 & 8.43 & $(2.56)$ & 7.47 \\
\hline Crown Cement & 5.26 & 3.69 & 1.60 & 1.30 & $(0.0069)$ & 1.65 \\
\hline Lafarge Holcim & 8.63 & 7.55 & 2.73 & 3.96 & 5.25 & 1.87 \\
\hline Meghna Cements Mills Ltd & - & 0.84 & 1.40 & 1.18 & 0.89 & 1.08 \\
\hline Mean & & 6.72 & 3.73 & 3.71 & .89 & \\
\hline
\end{tabular}

Source: Authors' Calculation Based on the Data of Annual Report

Table 1 shows that the ROA varied in each year, but mostly it showed a decreasing trend from 2015 to 2019 for each of the companies, although the data of Meghna group was not found (In 2015, Meghna group Cement Mills Limited did not publish their annual report). Moreover, Heidelberg and Crown both showed negative ROA during the year 2019. If we compare among the companies, Heidelberg had the highest ROA in 2015, which was 14.34, and Crown had the lowest ROA during 2019, which was negative 0.0069. The Mean technique for comparing the analysis refers to the Heidelberg Cement Bangladesh Ltd obtained a maximum mean(7.47), whereas Meghna Cements Mills Ltd achieved a minimum mean (1.08).

\subsection{Return on Equity (ROE)}

The Return on Equity is a measure of the profitability of a business with the equity (ROE= Net income/Equity).

According to Table 2, Heidelberg is showing a decreasing trend in terms of the ROE from 2015 to 2019, with a bit of increase in 2016, which was not sustainable eventually. Even the ROE of this company is showing a negative figure in the year 2019. On the other hand, Crown shows a gradual decrease in ROE, which fell from 11.07 to negative 1.92, which is not a good picture of the company's financial health. The other two companies- Holcim and the Meghna group, show quite ups and downs from 2015 to 2019. Among the four 
companies, Heidelberg had the highest ROE in 2015, which was 24.26, but at the same time, it had the lowest ROE in 2019, which was negative 6.66. Holcim showed the highest ROE in 2019, which was 9.15 .

Table 2. ROE of selected cement companies (In percentage)

\begin{tabular}{|l|c|c|c|c|c|c|}
\hline Companies & 2015 & 2016 & 2017 & 2018 & 2019 & Mean \\
\hline Heidelberg Cement Bangladesh Ltd & 24.26 & 26.97 & 17.09 & 15.58 & -6.66 & 13.245 \\
\hline Crown Cement & & & & & & \\
\hline Lafarge Holcim & 11.07 & 9.31 & 4.43 & 3.51 & -1.92 & 3.8325 \\
\hline Meghna Cements Mills Ltd & 11.47 & 9.94 & 3.71 & 6.12 & 9.15 & 7.23 \\
\hline Mean & - & 4.85 & 7.92 & 9.44 & 8.79 & 7.75 \\
\hline
\end{tabular}

Source: Authors' Calculation Based on the Data of Annual Report

Heidelberg Cement Bangladesh Ltd has a maximum mean value (13.25) for four years, and Lafarge Holcim had a minimum mean value. According to the mean technique in ROE, Heidelberg Cement Bangladesh Ltd had a good position.

\subsection{Earnings Per Share (EPS)}

Earnings per share is a significant financial measure, which indicates the profitability of a company. EPS are presented in Table 3.

Table 3. EPS of Selected Cement companies

\begin{tabular}{|l|c|c|c|c|c|c|}
\hline Companies & 2015 & 2016 & 2017 & 2018 & 2019 & Mean \\
\hline $\begin{array}{l}\text { Heidelberg Cement } \\
\text { Bangladesh Ltd }\end{array}$ & 24.81 & 26.69 & 14.21 & 12.59 & -4.57 & 12.23 \\
\hline Crown Cement & 5.01 & 4.45 & 2.13 & 1.69 & -0.89 & 1.85 \\
\hline Lafarge Holcim & 1.38 & 1.21 & 0.43 & 0.73 & 1.08 & 0.87 \\
\hline Meghna Cements Mills Ltd & - & 3.42 & 2.91 & 3.62 & 2.92 & 3.22 \\
\hline Mean & & 8.943 & 4.92 & 4.658 & -0.365 & \\
\hline
\end{tabular}

Source: Authors' Calculation Based on the Data of Annual Report

Among the selected companies, the Meghna group is showing the highest EPS (2.92) of 2019, although that is too low to depict a company's better performance. According to the data, Heidelberg had the lowest in 2019, which was negative 4.57, but it had the highest EPS in 2015. If we consider the case of Crown cement, it showed a decreasing trend throughout 2015-2019. According to the Mean value in EPS, Heidelberg Cement Bangladesh Ltd retained in highest position (12.23), and Lafarge Holcim is at the lowest position (0.87). 


\subsection{Current Ratio}

The purpose of the Current Ratio is to measure if a company can currently pay off short-term debts by liquidating its assets. $\mathrm{CR}$ can be measured as: $\mathrm{CR}=$ Current Assets/Current Liabilities. The current Ratios of the four companies are presented in Table 4.

From 2015 to 2019, both the Heidelberg and Crown cement companies showed a gradual decrease in Current Ratios. Heidelberg's CR fell from 1.96 to 0.77 in the 2015-2019 period. For the same duration, Crown's CR came down at 1.01 from 1.28. The other two companies, Lafarge Holcim and Meghna group, also reflected an overall decrease in CR over five years. In 2015, LafargeHolcim had the highest Current Ratio among the four, which was 2.96. Crown's performance was better than the others in 2019, which had a CR of 1.01. According to the mean technique of CR, LafargeHolcim has the maximum mean value of 2.03; on the other hand, Meghna Cements Mills Ltd has the lowest mean (1.01) among the four

Table 4. CR of selected cement companies

\begin{tabular}{|l|c|c|c|c|c|c|}
\hline Companies & 2015 & 2016 & 2017 & 2018 & 2019 & Mean \\
\hline $\begin{array}{l}\text { Heidelberg Cement } \\
\text { Bangladesh Ltd }\end{array}$ & 1.96 & 1.73 & 1.59 & 1.25 & 0.77 & 1.335 \\
\hline Crown Cement & 1.28 & 1.21 & 1.15 & 1.1 & 1.01 & 1.1175 \\
\hline LafargeHolcim & 2.96 & 3.21 & 2.72 & 1.29 & 0.88 & 2.025 \\
\hline $\begin{array}{l}\text { Meghna Cements Mills } \\
\text { Ltd }\end{array}$ & - & 1.07 & 1.05 & 1.13 & 0.8 & 1.0125 \\
\hline Mean & & 1.805 & 1.628 & 1.193 & 0.865 & \\
\hline
\end{tabular}

Source: Authors' Calculation Based on the Data of Annual Report

\subsection{Net Working Capital Ratio}

To measure the networking capital ratio, a company needs to calculate the liquidity of its assets. An increasing net working capital ratio indicates that the business is investing more in liquid assets than fixed assets. NWCR can be computed as follows:

NWCR $=($ Current Assets - Current Liabilities $) /$ Total Assets. NWCR is presented in Table 5.

The NWCR represent a decreasing trend for all the selected companies during the period of 2015-2019. Heidelberg showed the highest NWCR in 2015 (0.31) and lowest in $2019(-0.09)$. Comparing to the other three companies, Crown had at least a positive NWCR in 2019, which was 0.004; the others had a negative ratio in 2019. In the above analysis, it is observed that all the selected companies did not maintain enough NWC. The NWCR is not satisfactory during the study period. Heidelberg Cement Bangladesh Ltd here also maintains the highest mean value .125. Meghna Cement Mills Ltd. Obtained the lowest mean of 0.01. 
Table 5. NWCR of Selected Companies

\begin{tabular}{|l|c|c|c|c|c|c|}
\hline Companies & 2015 & 2016 & 2017 & 2018 & 2019 & Mean \\
\hline $\begin{array}{l}\text { Heidelberg Cement } \\
\text { Bangladesh Ltd }\end{array}$ & 0.31 & 0.28 & 0.22 & 0.09 & -0.09 & 0.125 \\
\hline Crown Cement & 0.13 & 0.1 & 0.07 & 0.05 & 0.004 & 0.056 \\
\hline LafargeHolcim & 0.25 & 0.28 & 0.27 & 0.06 & -0.04 & 0.1425 \\
\hline $\begin{array}{l}\text { Meghna Cements Mills } \\
\text { Ltd }\end{array}$ & - & 0.05 & 0.04 & 0.08 & -0.13 & 0.01 \\
\hline Mean & & 0.178 & 0.15 & 0.07 & -0.064 & \\
\hline
\end{tabular}

Source: Authors' Calculation Based on the Data of Annual Report

\subsection{Total Debt Ratio}

The total debt ratio is a quick way to see how much of a company's assets are available via debt. TDR can be computed as:

\section{$\mathrm{TDR}=$ Total Liabilities/Total Assets}

Table 6. Total Debt Ratio of Selected Cement Companies

\begin{tabular}{|l|c|c|c|c|c|c|}
\hline Companies & 2015 & 2016 & 2017 & 2018 & 2019 & Mean \\
\hline $\begin{array}{l}\text { Heidelberg Cement } \\
\text { Bangladesh Ltd }\end{array}$ & 0.41 & 0.45 & 0.46 & 0.46 & 0.62 & 0.4975 \\
\hline Crown Cement & 0.53 & 0.6 & 0.64 & 0.63 & 0.64 & 0.6275 \\
\hline LafargeHolcim & 0.24 & 0.24 & 0.26 & 0.35 & 0.43 & 0.32 \\
\hline $\begin{array}{l}\text { Meghna Cements Mills } \\
\text { Ltd }\end{array}$ & - & 0.83 & 0.82 & 0.87 & 0.9 & 0.855 \\
\hline Mean & & 0.53 & 0.545 & 0.578 & 0.6475 & \\
\hline
\end{tabular}

Source: Authors' Calculation Based on the Data of Annual Report

The TDR represent the increasing trend during the study period. Heidelberg Cement raised its TDR from 0.41 in 2015 to 0.62 in 2019 . The Crown, LafargeHolcim types of cement also showed a rising figure over times, which were 0.53 to 0.64 and 0.24 to 0.43 , respectively. The Meghna group represented the highest TDR in 2019, which was 0.90. Crown Cement has the highest mean value, .62, whereas Meghna Cement obtained the lowest mean of .32 .

\subsection{Assets Turnover Ratio}

This ratio is a good indicator of how good a company uses its assets to generate revenue. ATR can be computed as:

$\mathrm{ATR}=$ Sales/Average Total Assets 
Table 7. Assets Turnover Ratio of Selected Companies

\begin{tabular}{|l|c|c|c|c|c|c|}
\hline Companies & 2015 & 2016 & 2017 & 2018 & 2019 & Mean \\
\hline $\begin{array}{l}\text { Heidelberg Cement } \\
\text { Bangladesh Ltd }\end{array}$ & 1.07 & 1.04 & 1.12 & 1.32 & 1.18 & 1.165 \\
\hline Crown Cement & 0.64 & 0.53 & 0.64 & 0.76 & 0.73 & 0.665 \\
\hline LafargeHolcim & 0.59 & 0.57 & 0.59 & 0.57 & 0.5 & 0.5575 \\
\hline $\begin{array}{l}\text { Meghna Cements Mills } \\
\text { Ltd }\end{array}$ & - & 0.65 & 1.06 & 0.8 & 0.95 & 0.865 \\
\hline Mean & & 0.698 & 0.853 & 0.863 & 0.84 & 0.8131 \\
\hline
\end{tabular}

Source: Authors' Calculation Based on the Data of Annual Report

The ATR of all selected companies is unsatisfactory because the standard level of total assets turnover of 1.50 is acceptable for an industry. However, all other cement industries are below 1.50. Heidelberg Cement Bangladesh Ltd has the highest mean value 1.66, but LafargeHolcim has the lowest mean

\subsection{Accounts Receivable Turnover Ratio}

The ARTR ratio is to evaluate how quickly a company can collect funds from its customers. ARTR can be measured as:

ARTR $=$ Sales/Average Accounts Receivable

ARTR can be presented in table- 8 .

Table 8. Account Receivable Turnover Ratio of Selected Companies

\begin{tabular}{|l|c|c|c|c|c|c|}
\hline Companies & 2015 & 2016 & 2017 & 2018 & 2019 & Mean \\
\hline $\begin{array}{l}\text { Heidelberg Cement } \\
\text { Bangladesh Ltd }\end{array}$ & 10.23 & 9.26 & 8.59 & 13.65 & 13.22 & 11.18 \\
\hline Crown Cement & 8.46 & 5.86 & 5.24 & 4.3 & 3.53 & 4.7325 \\
\hline LafargeHolcim & 12.08 & 7.88 & 7.06 & 4.17 & 7.57 & 6.67 \\
\hline $\begin{array}{l}\text { Meghna Cements Mills } \\
\text { Ltd }\end{array}$ & - & 3.39 & 3.75 & 4.02 & 6.77 & 4.4825 \\
\hline Mean & & 6.598 & 6.16 & 6.535 & 7.7725 & \\
\hline
\end{tabular}

Source: Authors' Calculation Based on the Data of Annual Report

The ARTR represented the decreasing trends for Crown and LafargeHolcim cement. The other two, Heidelberg and Meghna group, showed increasing trends of ARTR from 2015 through 2019. Account Receivable Turnover Ratio mean technique Heidelberg Cement Bangladesh Ltd has the highest mean 11.18 Meghna Cements Mills Ltd has the lowest mean of 4.48 
The study of comparative analysis about selected cement companies visualized several findings. Based on Mean Technique, Heidelberg Cement Bangladesh has a good position, and in several indicators, Meghna Cement Mills Ltd. It is at the lowest position and profitability analysis Heidelberg Cement Company scored at the highest position than the others. Contrarily Crown Cement scored lowest along with the average performance of remaining. The current ratio measurement indicates that LafargeHolcim is at the highest condition. It refers to the solvent ability to cover its short term liabilities by cash.

Nevertheless, the other three companies are relatively in a weak position. Leverage ratio analysis indicates Meghna Cement Company is in most favorable condition than others. Based on turnover ratio analysis, Heidelberg Cement Company is in the highest position than the others. Crown Cement is in the lowest position. The other two companies show the average results. All the companies should increase their ATR. The above analysis indicates that Heidelberg Cement Company is in a relatively strong position to collect the credit more efficiently. The other three companies are in a safe position. However, Crown Cement, LafargeHolcim Cement and Meghna Cement should increase their ARTR.

Some recommendations based on the findings of selected cement companies are given below:

The study recommended that the selected cement companies should focus on cost reduction.

a. To hold a balanced liquidity position, cement companies should invest their extra liquid assets to increase production volume.

b. The expense ratio is an essential factor for all cement companies. So, they should prioritize reducing the expense ratio.

c. The study recommends that cement companies expand their businesses to achieve an optimum size and enjoy economies of scale. An optimum size will ultimately strengthen financial performance.

d. To ensure maximum profitability, an appropriate cost accounting system should be set up in cement companies.

e. Cement companies should pay more attention to the volume of capital and leverage for better financial performance.

f. To enlarge the business and generate more revenue, cement companies should expand their sales.

\section{Conclusion}

The objective of this study was to evaluate the financial health of cement companies in Bangladesh during the period 2015-2019. The financial performance of the selected cement companies was measured with the use of various ratio analyses. Results of the study show that ROA, ROE and EPS are the factors that significantly affect the performance of cement companies in Bangladesh. The study also found that Heidelberg Cement Company is in a relatively strong position on the basis of mean analysis of the financial performance indicators. The other three companies are in a safe position. Thus, for further growth and development of the cement companies, the study recommended that management take some strategic steps like introducing a mechanism that reduces costs, developing human resources development programs, relaxing pricing rules etc. Moreover, modern techniques could be 
adopted for asset management. The findings of this research are expected to contribute to a better understanding of the financial health of cement companies in Bangladesh.

\section{References}

Abedin, S. N. (2020). Bangladesh cement industry amid COVID-19 Outbreak. Retrieved from https://www.intercem.com/Intercem-Insights/INTERCEMInsights/ArtMID/718/ArticleID/1849/Bangladesh-Cement-Industry-amid-COVID19-Outbreak

Annual Report, Crown Cement (2015-2019).

Annual Report, Heidelberg Cement (2015-2019).

Annual Report, LafargeHolcim Bangladesh (2015-2019).

Annual Report, Meghna Cement Mills (2015-2019).

Bangladesh Bank (2021). Monetary Policy Statement (FY2020-21). Retrieve from:https://www.bb.org.bd/openpdf.php

Bangladesh Business Directory (n. d.) Manufacturing companies in Bangladesh, Retrieve from: https://www.dnb.com/business-directory/companyinformation.manufacturing.bd.html

Chhatak Cement Factory (2020). Retrieve from: https://en.wikipedia.org/wiki/Chhatak_Cement_Factory, Date-2021-03-29.

Daryanto, W. M. (2018). Measuring financial performance of cement industry during infrastructure development in Indonesia. South East Asia Journal of Contemporary Business, Economics and Law, 16(1), p. 44-56.

Dhivya, Shobanapriya, Devika, Karthika \& Bakiyaraj (2017). Financial performance of cement industry of ACC limited. International Journal of Creative Research Thoughts, 5(4), p.1627-1635.

Gopi, K. T. (2018). The study on financial performance of cement industry in India. Asian Journal of Managerial Science, 7(2), p. 16-20.

Hoque, M. A., Mia, M. A., \& Anwar, A. M. R. (2015). Working capital management and profitability: A study on cement industry in Bangladesh, Research Journal of Finance and Accounting, 6(7), p. 18-28

Hossain, M. K. \& Huq, S. M. U. (2014). Credit strength of cement industry in Bangladesh, Management Studies and Economic Systems, 1(2), p. 99-114,

Kaura M. N. \& Balasubramanian, C. S. (1979). Inter-firm comparison of financial performance of selected cement companies in India: A cause and effect approach. ASCI Journal of Management, 9(1), 1979, p. 50-67.

Lightcastle Analytic Wing (2019). Building a concrete future. Retrieved from https://www.lightcastlebd.com/insights/2019/03/20/cement-in-bangladesh-buildinga-concrete-future, December 2020.

Majeed, M. M., Ilyas, B. \& Nasir, M. (2017). Analysis of financial progress of cement industry in Pakistan, Research Journal of Finance and Accounting, 8(19), p. 7-12. 
Mizan, A. N. K. \& Hossain, M. M. (2014). Financial soundness of cement industry of Bangladesh, American Journal of Trade and Policy, 1(1), p. 16-22.

Muslumov, A. (2005). The financial and operating performance of privatized companies in the Turkish cement industry. METU Studies in Development, 32(1), p. 59-101.

Rajashekar, H. \& Keshavraz, A. R. (2019). The impact of environmental management accounting of financial performance of cement companies in India. International Journal of Management Studies, 2(3). DOI:10.18843/IJMS/V6I2(3)/03.

Rezina, S., Ashraf, A. \& Khan, A. (2020). An inferential study on the profitability determinates of the cement industry in Bangladesh. Asian Finance and banking review, 4(2), P.8-21.

Saeedi, A. \& Mahmoodi, I. (2011). Capital structure and firm performance: evidence from Iranian companies, International Research Journal of Finance and Economics (70), p. 20-29.

San, O. T. \& Heng, T. B. (2011). Capital structure and corporate performance of Malaysian construction sector, International Journal of Humanities and Social Science, 1(2), p. 28-36.

Soni, S. (2018). A study on the financial performance of JK cement, International Journal of Research and Review, I(5), p. 115-119.

Teri (2017). Cement industry trends report. Energy \& resource institute , P.17

UN (2014). 2014 revision of the world urbanization prospects. Retrieve from: https://www.un.org/en/development/desa/publications/2014-revision-worldurbanization-prospects.html

Venkatacham, R. \& Kasthuri, V. (2016). A study on the financial performance of the cement industry in India. International Journal of Applied Research, 2(9), p. 778-780.

\section{Copyrights}

Copyright for this article is retained by the author(s), with first publication rights granted to the journal.

This is an open-access article distributed under the terms and conditions of the Creative Commons Attribution license (http://creativecommons.org/licenses/by/4.0/) 